\title{
FIRM RESOURCES FOR INTERNATIONALIZATION OF SMES FROM EMERGING COUNTRIES: A MULTIMETHOD STUDY
}

\author{
NATÁLIA C. WINCKLER ${ }^{1}$ \\ (iD) https://orcid.org/0000-0003-2449-7827 \\ AURORA C. ZEN ${ }^{1}$ \\ (iD) https://orcid.org/0000-0003-4078-4359 \\ FRÉDÉRIC PREVOT ${ }^{2}$ \\ (iD) https://orcid.org/0000-0001-6523-3794
}

To cite this paper: Winckler, N. C., Zen, A. C., \& Prevot, F. (2022). Firm resources for internationalization of SMEs from emerging countries: A multimethod study. Revista de Administração Mackenzie, 23(1), 1-31. doi:10.1590/1678-6971/eRAMR220165

Submission: Aug. 25, 2020. Acceptance: Feb. 10, 2021.

\footnotetext{
1 Federal University of Rio Grande do Sul (UFRGS), Porto Alegre, RS, Brazil.

2 Kedge Business School, Marselha, France.
}

\section{(c) $\mathbf{B Y}$}




\section{ABSTRACT}

Purpose: This article investigates and classifies firm resources for the internationalization of small and medium enterprises (SMEs) from emerging countries.

Originality/value: SMEs from emerging countries in global markets evidence their more restricted access to resources for internationalization. The mainstream international business literature classifies firm's resources identified in large companies from developed economies. This research classifies firms' internationalization resources located in different emerging countries based on a systematic literature review (SLR) and interviews. This paper contributes to the theoretical development about the internationalization of SMEs from emerging countries, indicating the importance of organizational resources in this process.

Design/methodology/approach: This paper presents an exploratory research developed in two stages: a SLR on emerging countries and interviews with experts, institutions, and SMEs about the Brazilian context. Bibliographic research and an interview with semi-structured script were adopted as data collection techniques. Interviews were analyzed with NVivo software using content analysis technique and providing categorization of resources.

Findings: Up to 2016, 15 works mentioned resources for the internationalization of SMEs from emerging countries and seven were done in Asia. We identified 72 resources in ten emerging countries. Organizational resources predominate. The use of financial resources in Brazil contradicts the trend in other emerging countries. More tangible resources seem less strategic for SMEs' internationalization from emerging countries when compared to more intangible resources, as organizational ones.

\section{KEYWORDS}

Resource-based view. Systematic review. Emerging countries. Small and medium enterprises. Export. 


\section{INTRODUCTION}

The resource-based approach is fundamental in the management literature and has been applied to the analysis of companies growth (Nason \& Wiklund, 2018) and, specifically, to their internationalization (c, Autio, Gelbūda, \& Šarapovas, 2015; Acikdilli, Mintu-Wimsatt, Kara, \& Spillan, 2020). In this perspective, resources are essential to create and sustain competitive advantage in global markets and guide business strategies (Nanda, 1996). In internationalization strategies, the smaller size of the firm in emerging countries can make access and resource use more difficult, negatively affecting the creation of competitive advantage (Williams, 2008).

Emerging countries' companies have become a relevant research topic (Peng, Wang, \& Jiang, 2008; Chandra, Paul, \& Chavan, 2020; Acikdilli et al., 2020). Contextual and institutional changes resulting from the economic openness of these countries are challenging for both local and foreign companies that wish to enter the country. Small and medium enterprises (SMEs) are relevant for the economic growth of emerging countries; however, they take longer to internationalize when compared to firms from more economically developed countries (Chandra et al., 2020).

Although they suffer greater restrictions for accessing resources and entering the international market, SMEs seem to better absorb the advantages of their countries' economic openness (Ketkar \& Acs, 2013). As shown by Chandra et al. (2020), SMEs face a lack of financial and physical resources, hard access to information and to structures for product quality certification, as well as lack of managerial resources that result from experience in the foreign market and their size. To overcome these and other difficulties, companies need to know the markets, master political and economic issues of the target countries, and count on specific resources and technologies (Torrens, Amal, \& Tontini, 2014).

The institutional and legal environment, the relationship between internationalization and the firm's domestic market, and the risks involved in the internationalization process relate to the types of resources controlled by firms (Pattnaik \& Elango, 2009). In emerging countries, SMEs do not take advantage of traditional and institutional resources and adapt their strategy to the resources that exist in their home country (Gaur, Kumar, \& Singh, 2014).

There are two types of resources used by a company: a firm's specific resources and a country's specific resources (Fahy, 2002). Kazlauskatė et al. (2015) analyze the motivations and applicability of the resource-based view (RBV) for the study of emerging countries' SMEs. Studies developed 
by Gaur et al. (2014), Torrens et al. (2014), and Chandra et al. (2020) identify some resources that influence the internationalization of SMEs from emerging countries, but do not classify them at the firm or country level, neither do they suggest models not validated in the literature yet. Winckler (2018) ranks resources empirically, checking only country resources and highlighting the literature gap regarding firm-level resources. Thus, we propose the following research question:

- What resources are exploited and incorporated by emerging countries' SMEs during the internationalization process?

This article seeks to investigate and classify the resources for the internationalization of emerging countries' SMEs. Given the exploratory analysis of the phenomenon, we chose to use classifications validated by previous studies, such as the RBV resource classification proposed by Grant (1991). We then checked with experts for its update and application to our study. We carried out a multimethod study to survey such resources, combining a systematic literature review (SLR) of studies in different emerging countries and interviews with experts, institutions, and SMEs in Brazil. After classifying them by using the categories proposed by Grant (1991) for firm resources, we compared them with the resources already identified in the previous stage of the research in order to seek the existence of specific resources of Brazilian SMEs.

The major contribution of this study is to highlight strategic resources for the internationalization of emerging countries' SMEs, filling the literature gap on this topic (Kazlauskatè et al., 2015). Thus, we advance from previous studies since we conducted a multimethod study, combining an exploratory survey of resources mentioned in the literature, in-depth interviews, and Grant's (1991) validated classification. In addition, since institutional change is a characteristic of emerging countries, this research can contribute to public policies appropriate to SMEs' resource demands and to overcome global competitiveness challenges arising from lack of resources, high risks, and transaction costs (Ketkar \& Acs, 2013).

The article has six sections. In addition to this introduction, there are two sections of literature review on RBV and resources for the internationalization of emerging countries' SMEs. In the fourth section, we describe the method, the criteria adopted for SLR, and the interviewees' profile in the exploratory research. The fifth section presents the main results and analyses of SLR and exploratory research. The sixth section reports the final remarks and suggestions for future research. 


\section{THEORETICAL REVIEW}

\subsection{The resource-based view}

Resources are the firm's tangible and intangible assets (Wernerfelt, 1984), internal, shared, or accessible. These assets are the basis of the RBV theoretical approach, in which firms' individual resources and their inherent characteristics (Kraaijenbrink, Spender, \& Groen, 2010) are connected to their strategy (Grant, 1991). Hence, firms' distinct results can be explained by the attributes of their resources (Prévot, Brulhart, \& Guieu, 2010), especially when they cannot be assigned to differences in the conditions of their sector of activity (Peteraf, 1993).

A resource must be valuable because it exploits opportunities or neutralizes threats in the firm's environment; it is rare among the firm's current and potential competitors; and it is imperfectly imitable, and without strategically equivalent substitutes (Barney, 1991). In addition, other factors are relevant to its competitive advantages, such as the resource's durability, the speed with which other firms can imitate it, its lower capacity of transfer and replication, or a firm's difficulty in imitating the success of another firm's resource (Grant, 1991).

Classical strategy authors have proposed different classifications for resources (Penrose, 1959; Wernerfelt, 1984; Barney, 1991) and agree upon the importance of heterogeneity in generating returns for the firm through competitive advantage. Penrose's (1959) classification was the basis for subsequent categorizations. For the author, resources are assets available to the firm for use according to a management decision and comprise two types: physical and human.

Later, Grant (1991) included other types of firm resources: financial, technological, reputational, and organizational, such as: patents, brands, ability to retaliate, process technology, plant size, product technology, service capacity, distribution and commercialization, organizational style, and employees' skills. The author, however, did not separate them explicitly (Grant, 1991), and others have complemented his classification, such as Carvalho, Prévot, and Machado (2014) (Figure 2.1.1).

Resources can be tangible or intangible (Grant, 1991). Tangible resources are hardly strategic, as they are easily found in the market, as is the case of physical resources. On the other hand, intangible resources, such as reputational, are more difficult to imitate since they result from a company's 
development; their transfer will only occur through the firm's acquisition (Grant, 1991; Carvalho et al., 2014; Kazlauskatė et al., 2015).

(Figure 2.1.1)

STRATEGIC RESOURCES IN STUDIES THAT USED RBV

\begin{tabular}{|c|c|}
\hline Resource type & Examples \\
\hline \multirow{3}{*}{ Physical } & Equipment \\
\hline & Size/scale \\
\hline & Location \\
\hline \multirow{7}{*}{ Human } & Training \\
\hline & Competence \\
\hline & Tacit knowledge \\
\hline & Entrepreneurship \\
\hline & Involvement and managerial style \\
\hline & Social capital \\
\hline & Incentives \\
\hline \multirow{8}{*}{ Organizational } & Information technology management and use \\
\hline & Advertising/marketing \\
\hline & Quality \\
\hline & Internal processes/routines \\
\hline & Flexibility for change \\
\hline & Relationship with the environment \\
\hline & Organizational culture \\
\hline & Planning \\
\hline \multirow{4}{*}{ Technological } & Control and coordination systems \\
\hline & Patents \\
\hline & Innovations \\
\hline & Technology investments \\
\hline \multirow{3}{*}{ Financial } & Capital \\
\hline & Budget/earnings and cost control \\
\hline & Types of credit \\
\hline
\end{tabular}

(continue) 


\section{(Figure 2.1.1 (conclusion))}

STRATEGIC RESOURCES IN STUDIES THAT USED RBV

\begin{tabular}{ll}
\hline \multicolumn{1}{c}{ Resource type } & \multicolumn{1}{c}{ Examples } \\
\hline \multirow{3}{*}{ Reputational } & Brand \\
\cline { 2 - 2 } & Relationship with customers \\
\cline { 2 - 2 } & Image/reputation \\
\hline
\end{tabular}

Source: Adapted from Carvalho et al. (2014, p. 509).

Firm resources relate directly to its internationalization process; thus, it exploits existing resources when entering a new market and then starts looking for other resources (Kamakura, Ramón-Jerónimo, \& Gravel, 2012). In addition, firm size indicates its resource base (Contractor, Kumar, \& Kundu, 2007). In emerging countries, where most firms are smaller, the available resources are different from those used by firms in developed countries (Gaur et al., 2014). Studies on resources for the internationalization of smaller companies from emerging countries, such as those by Torrens et al. (2014) and Gaur et al. (2014), are exploratory and describe some of the resources used by them; however, they suggest new analysis models, not based on proposals accepted and spread in the literature (Grant, 1991).

\subsection{Resources for the internationalization of emerging countries' SMEs}

Emerging countries have an increasing number of firms that target the foreign market (Cavusgil, Ghauri, \& Akcal, 2013; Hernandez. \& Guillen, 2018; Bhaumik, Driffield, Gaur, Mickiewicz, \& Vaaler, 2019). Compared to firms in developed countries, emerging countries' SMEs enter the global market late because economic instability and high operating costs are disadvantages of their home countries (Fleury \& Fleury, 2007). In addition, they face other limitations for being SMEs, such as more restricted access to resources (Gaur et al., 2014), which conditions the beginning of the internationalization process to limited demand in the domestic market (Wright, Westhead, \& Ubasaran, 2007).

SMEs must prepare themselves to operate across borders, developing market research, committing their human and financial resources, adapting product lines for a new market, and knowing the legislation on internationalization (Torrens et al., 2014; Wu \& Deng, 2020). They should consider 
the sector of activity, the company's support system, the ability to sell the product or service abroad, and the costs to access those markets. Many SMEs do not have goods and services tradable in the foreign market and find barriers such as lack of wish to export or reluctance to commit resources overseas (Wright et al., 2007).

Firms from emerging countries use non-traditional resources when compared to those of firms from developed countries. Examples of traditional resources from firms in developed economies are international experience and technological and market capacity. In contrast, non-traditional resources are cheap labor or the firm's dominant position in the domestic market (Gaur et al., 2014).

Studies based on RBV and addressing the Brazilian context have identified the relationship between some resources and SMEs' internationalization. Torrens et al. (2014) analyzed the determinants of export performance, by considering two types of resources as variables for analysis: organizational resources, such as the beginning of exports, firm experience, visits to foreign markets, and relationship with governments and technological hubs' networks, and management resources, like sales and profitability as incentives, perception of barriers to Brazilian products, and manager's knowledge on international legislation and activities. The authors highlight two constructs of organizational and management resources, showing that resources and international experience affect the export performance of SMEs. In this case, the classification adopted disregards firm resources, such as physical.

Oura, Zilber, and Lopes (2016) address the Brazilian perspective of resources and internationalization, observing that innovative capacity and international experience affect export performance, the latter being more relevant than the former.

Winckler (2018) conducted a third study, identifying countries' resources for internationalization and their relationship with international performance. The author observed that there is no relationship between the use of the country's resources and SMEs' international performance and suggested that firm resources could be potentially responsible for higher international performance, despite not analyzing them.

Extending this analysis to other emerging countries, in a survey carried out for this research, we found incipient and recent empirical studies on the subject developed in the last two decades (Kazlauskatè et al., 2015). The resources identified in these studies may indicate these firms' behavior in the international market. 


\section{METHOD}

This is an exploratory research, with a qualitative approach, which took place in two stages: an SLR, followed by exploratory research with interviews with experts, institutions, and SMEs, in the Brazilian context. We used SLR to explore, discover, and develop a discussion around an issue through a detailed research protocol which allows following certain research steps with the least possible researcher's bias (Tranfield, Denyer, \& Smart, 2003). We employed this data collection technique for articles published online on the Scopus platform, following specific research, organization, and data analysis criteria. The choice of this platform arose from scientific evidence on the consistency of the results regarding the the organization of the articles (Falagas, Pitsouni, Malietzis, \& Pappas, 2008). In addition, there is greater control over the research when using a single database, which enables a more accurate future replication of the methodology.

We used the keywords "internationali*" AND "resource*" AND "SME" or "small and medium*" AND "emerging" in order to find results for resources, internationalization, SMEs, and emerging countries. We chose documents published until August 17, 2016, in English and Portuguese, resulting in 32 articles. Figure 3.1 presents the research criteria adopted in the systematic literature review.

(Figure 3.1)

RESEARCH CRITERIA ADOPTED IN THE SYSTEMATIC LITERATURE REVIEW

\begin{tabular}{ll}
\hline \multicolumn{1}{c}{ Criterion } & \multicolumn{1}{c}{ Topics } \\
\hline For paper research & $\begin{array}{l}\text { "internationali*" AND "resource*" AND "SME" or "small and } \\
\text { medium }{ }^{\star \prime} \text { AND "emerging" }\end{array}$ \\
\hline For including papers in the research & Domain refinement: "social sciences" \\
\hline For including papers in the research & Language refinement: "English" OR "Portuguese" \\
\hline For excluding papers in the research & Theme refinement from abstract reading \\
\hline
\end{tabular}

Source: Elaborated by the authors.

Reading the abstracts, followed by classification according to the research topic, resulted in 21 articles for download and full reading. Of these, we excluded one article that was not available for download. We read 20 articles, removing three that deviated from the research topic. Hence, 
we selected only the 15 empirical articles, classified by: authors, objective, country of study, type of study (empirical, non-empirical, qualitative, or quantitative; form of data collection; type of analysis), criteria for SME classification, journal name, and year of publication. We systematized them in an electronic spreadsheet. We identified firms' resources for internationalization after two detailed readings of each selected article. After identification, we did a third reading to list the resources in an electronic spreadsheet. Due to variations in resources' names among the articles analyzed, we conducted five rounds of discussion, classification, and review of resources, in order to assemble and classify them according to Grant's (1991) categories.

In the second stage, we carried out 18 interviews, with five experts in foreign markets, five SMEs, and eight institutions, with an average duration of 74 minutes each (Figure 3.2). The interviews took place in the first half of 2017. For the selection of interviewees, we used the snowball technique. Among the institutions, there are those that work at the national and regional levels, financing and logistics institutions, which have specific programs to encourage and support internationalization. Experts and institutions suggested the SMEs in order to get information from these companies' experience. We finished this step when we reached a degree of saturation or repetition of the resources mentioned in the interviews.

The interview script had questions on two topics: the internationalization process of Brazilian companies (motivations, obstacles, incentives, and performance) and the most important resources for the internationalization of Brazilian SMEs, based on Grant's (1991) classification. We also questioned the profile and the internationalization process of SMEs when compared to larger companies. Interviews lasted between 55 and 105 minutes, and we transcribed them for further analysis.

\section{(Figure 3.2)}

INTERVIEWEES' PROFILE IN EXPLORATORY RESEARCH

\begin{tabular}{ccc}
\hline Organization & Interviewee & $\begin{array}{c}\text { Interview duration } \\
\text { (in minutes) }\end{array}$ \\
\hline Institutions & Position & \\
\hline
\end{tabular}

Brazilian Agency for the Promotion of Exports and Investments (Apex)

Coordinator for competitiveness

$80 \mathrm{~min}$

\begin{tabular}{llc}
\hline Bank of Brazil (BB) & Regional manager of foreign trade & 80 min \\
\hline $\begin{array}{l}\text { Regional Bank for the Development } \\
\text { of the Extreme South (BRDE) }\end{array}$ & Planning manager & 50 min \\
\hline
\end{tabular}




\section{(Figure 3.2 (conclusion))}

\section{INTERVIEWEES' PROFILE IN EXPLORATORY RESEARCH}

\begin{tabular}{|c|c|c|}
\hline Organization & Interviewee & \multirow{2}{*}{$\begin{array}{l}\text { Interview duration } \\
\text { (in minutes) }\end{array}$} \\
\hline Institutions & Position & \\
\hline $\begin{array}{l}\text { Brazilian Post and Telegraph } \\
\text { Company (ECT) }\end{array}$ & Assistant for foreign trade & $60 \mathrm{~min}$ \\
\hline ExportRS & Coordinator & $65 \mathrm{~min}$ \\
\hline $\begin{array}{l}\text { Federation of Industries of Rio Grande } \\
\text { do Sul State (Fiergs) }\end{array}$ & $\begin{array}{l}\text { Technical assistant (1) } \\
\text { Technical assistant (2) } \\
\text { Junior analyst (3) }\end{array}$ & $95 \mathrm{~min}$ \\
\hline Brazilian Institute for Wine (Ibravin) & $\begin{array}{l}\text { Promotion analyst (1) } \\
\text { Promotion assistant (2) }\end{array}$ & $105 \mathrm{~min}$ \\
\hline \multirow{2}{*}{$\begin{array}{l}\text { Brazilian Support Service for Micro } \\
\text { and Small Firms (Sebrae) }\end{array}$} & Market analyst (Sebrae - RJ state) & $55 \mathrm{~min}$ \\
\hline & Market analyst (National Sebrae) & $55 \mathrm{~min}$ \\
\hline SMES & Position & \\
\hline $\begin{array}{l}\text { Service company in information } \\
\text { technology }\end{array}$ & Commercial leader & $66 \mathrm{~min}$ \\
\hline Organic beverages industrial company & Marketing director & $60 \mathrm{~min}$ \\
\hline Biscuit industrial company & Manager of foreign trade & $80 \mathrm{~min}$ \\
\hline Cachaça industrial company & Commercial director & $110 \mathrm{~min}$ \\
\hline Wine industrial company & Export supervisor & $70 \mathrm{~min}$ \\
\hline Experts & Position & \\
\hline Expert 1 & $\begin{array}{l}\text { Expert in foreign trade and chef } \\
\text { executive officer (CEO) of a } \\
\text { multinational company }\end{array}$ & $50 \mathrm{~min}$ \\
\hline Expert 2 & Director of trading firm & $80 \mathrm{~min}$ \\
\hline Expert 3 & $\begin{array}{l}\text { Professor, researcher, and business } \\
\text { consultant }\end{array}$ & $85 \mathrm{~min}$ \\
\hline Expert 4 & $\begin{array}{l}\text { Professor, researcher, and business } \\
\text { consultant }\end{array}$ & $110 \mathrm{~min}$ \\
\hline Expert 5 & Professor and researcher & $55 \mathrm{~min}$ \\
\hline
\end{tabular}

Source: Elaborated by the authors. 
We analyzed the data of the interviews through the content analysis technique (Bardin, 2011). We imported the content of each interview into the NVivo software, creating "Knots" (where the researcher groups elements of the same nature or category of analysis) according to the interviewee's type of organization (SME, institution, or expert). Later, each passage where we identified a resource was classified according to Grant's (1991) resource categories. After analyzing the interviews, we exported the set of identified resources to an electronic spreadsheet in order to compare the results of the two research stages (Figure 4.2).

\section{RESULTS AND ANALYSES}

The results show 15 papers (Figure 4.1) involving 40 different authors, with only one of them participating in two articles. The remaining 13 articles did not have any repeated authors. The articles were published between 2008 and 2016, most frequently in 2013 (three), 2014 (four), and 2015 (three). In 2016, we found two papers published until the end of data collection. There are 12 different journals, one of which published two articles from the sample (Journal of Asia Business Studies), and the other published three articles from the sample (Journal of International Entrepreneurship), which shows the relatively high representation of these two journals on this topic if we consider the whole sample. Although publications have increased significantly until 2017, at the time of the research, it was still a little explored subject.

The classification criteria for SMEs in each article reflect those adopted in the countries where the studies took place. The number of employees ranged from "less than 100" to "less than 3,000", with "less than 500" being the most frequent. The papers by Keen (2013), Manolova, Manev, and Gyoshev (2014), and Che Senik, Mat Isa, Md Sham, and Ayob (2014) do not present their criteria.

The studies took place mainly in Asia (seven studies: one in India; three in China; three in Malaysia), and South America (three studies: two in Brazil; one in Argentina). The rest addressed Jamaica, Russia, Bulgaria, Romania, and Turkey. The surveys are mostly multisector (nine) and quantitative (ten); the techniques used are survey and statistical analysis. Qualitative studies (four) use in-depth interviews, content analysis, and categorization. We identified only one mixed study. 


\section{(Figure 4.1)}

ARTICLES SELECTED BY THE SYSTEMATIC LITERATURE REVIEW

\begin{tabular}{|c|c|c|c|c|}
\hline Year & Authors & Journal & $\begin{array}{l}\text { Country } \\
\text { of study }\end{array}$ & Sector \\
\hline 2016 & Oura, Zilber, and Lopes & International Business Review & Brazil & Industry \\
\hline 2016 & Zhang, Wheeler, Gao, and Kwon & Journal of Asia Business Studies & China & $\begin{array}{l}\text { Manufacturing } \\
\text { industry }\end{array}$ \\
\hline 2015 & Ayob, Ramlee, and Rahman & Journal of International Entrepreneurship & Malaysia & $\begin{array}{l}\text { Manufacturing } \\
\text { industry }\end{array}$ \\
\hline 2015 & Cardoza, Fornes, Li, Xu, and Xu & Asia Pacific Business Review & China & Multisector \\
\hline 2015 & Lafuente, Stoian, and Rialp & $\begin{array}{l}\text { Journal of Small Business and Enterprise } \\
\text { Development }\end{array}$ & Romania & Multisector \\
\hline 2014 & Ahmad & Journal of Asia Business Studies & Malaysia & Multisector \\
\hline 2014 & Torrens, Amal, and Tontini & Revista Brasileira de Gestão de Negócios & Brazil & $\begin{array}{l}\text { Manufacturing } \\
\text { industry }\end{array}$ \\
\hline 2014 & $\begin{array}{l}\text { Che Senik, Mat Isa, Md Sham, } \\
\text { and Ayob }\end{array}$ & Jurnal Pengurusan & Malaysia & $\begin{array}{l}\text { Experts from } \\
\text { different areas }\end{array}$ \\
\hline 2014 & $\begin{array}{l}\text { Volchek, Jantunen, and } \\
\text { Saarenketo }\end{array}$ & Journal of International Entrepreneurship & Russia & Multisector \\
\hline 2013 & Manolova, Manev, and Gyoshev & International Small Business Journal & Bulgaria & Multisector \\
\hline 2013 & Keen & $\begin{array}{l}\text { International Journal of Entrepreneurship } \\
\text { and Small Business }\end{array}$ & Argentina & Multisector \\
\hline 2013 & Lee, Lee, and Kwak & Asian Business and Management & China & Multisector \\
\hline 2011 & Javalgi and Todd & Journal of Business Research & India & Multisector \\
\hline 2009 & Kocak and Abimbola & International Marketing Review & Turkey & Multisector \\
\hline 2008 & Williams & Journal of International Entrepreneurship & Jamaica & $\begin{array}{l}\text { Manufacturing } \\
\text { industry and } \\
\text { agriculture }\end{array}$ \\
\hline
\end{tabular}

Source: Elaborated by the authors.

While SLR showed 37 different resources, which did not include all the categories of firm resources (Grant, 1991), the exploratory research registered 64 resources and covered all categories. Adding the resources from both surveys (systematic review and exploratory research), we have 72 firm resources for internationalization of SMEs from emerging countries, of which eight resources appear only in the systematic review and 35 only in the exploratory research. Of the 72 resources, 29 appear in both surveys (Figure 4.2). 
Based on Grant (1991), the general ranking points to three physical resources, five financial, 12 human, 35 organizational, nine reputational, and eight technological. The only type of resource that we did not identify as strategic for internationalization in the systematic review was the physical one, mentioned with reservations by part of the interviewees as a type of "basic" resource that does not contribute to creating competitive advantage in internationalization. Resources such as idle capacity, productive capacity, and raw material availability can be strategic (Victer, 2014) depending on the sector of activity, besides being more easily imitated (Fahy, 2002). As mentioned by an interviewee from Apex,

[...] these physical resources vary widely from sector to sector. In labor-intensive sectors, raw material is available in the country today. In addition, there is, in this moment of crisis, an idle capacity that would allow companies to go abroad.

Given that the studies analyzed are mostly multisectoral, sectors' specificities were not identified, and possibly physical resources are common and do not create competitive advantage. This is also the perception of some experts interviewed in the exploratory stage.

\section{(Figure 4.2)}

RESOURCES FOR THE INTERNATIONALIZATION OF SMES FROM EMERGING

COUNTRIES IDENTIFIED BY THE SYSTEMATIC REVIEW VERSUS THOSE IDENTIFIED IN EXPLORATORY RESEARCH

\begin{tabular}{llcc}
\hline \multirow{2}{*}{ Category } & \multicolumn{1}{c}{ Resource description } & $\begin{array}{c}\text { Systematic } \\
\text { review }\end{array}$ & $\begin{array}{c}\text { Exploratory } \\
\text { research }\end{array}$ \\
\hline \multirow{3}{*}{ Physical } & Idle capacity & $\times$ \\
\cline { 2 - 4 } & Capacity to meet external demand & $\times$ \\
\cline { 2 - 4 } & Available raw material & $\times$ \\
\hline \multirow{3}{*}{ Financial } & Access to third party resources & $\times$ & $\times$ \\
\cline { 2 - 4 } & Fnternal liquidity and available tangible resources & $\times$ & $\times$ \\
\cline { 2 - 4 } & Financial resources for innovation & $\times$ & $\times$ \\
\cline { 2 - 4 } & Financial resources for international expansion & $\times$ & $\times$ \\
\cline { 2 - 4 } & Own financial resources & & $\times$ \\
\hline
\end{tabular}


(Figure 4.2 (continuation))

RESOURCES FOR THE INTERNATIONALIZATION OF SMES FROM EMERGING COUNTRIES IDENTIFIED BY THE SYSTEMATIC REVIEW VERSUS THOSE IDENTIFIED IN EXPLORATORY RESEARCH

\begin{tabular}{|c|c|c|c|}
\hline Category & Resource description & $\begin{array}{l}\text { Systematic } \\
\text { review }\end{array}$ & $\begin{array}{l}\text { Exploratory } \\
\text { research }\end{array}$ \\
\hline \multirow{12}{*}{ Human } & Access to export experts & & $x$ \\
\hline & Articulation of work team & $x$ & $x$ \\
\hline & Entrepreneurial behavior towards internationalization & & $x$ \\
\hline & Internationalization team & & $x$ \\
\hline & Managers' international experience & $x$ & $x$ \\
\hline & Employees' academic background & $x$ & \\
\hline & Managers' academic background & $x$ & $x$ \\
\hline & $\begin{array}{l}\text { Foreign trade manager or with knowledge in } \\
\text { international business practices }\end{array}$ & $x$ & $x$ \\
\hline & Managers' interpersonal skills & $x$ & $x$ \\
\hline & Specialized labor for specific demands of the market & $x$ & $x$ \\
\hline & People fluent in other languages & & $x$ \\
\hline & Professionals with sales ability & & $x$ \\
\hline \multirow{13}{*}{ Organizational } & Access to a structure for training and capacity building & $x$ & $x$ \\
\hline & Cooperation or supply agreements for multinationals & $x$ & $x$ \\
\hline & Strategic alliances for internationalization & $x$ & $x$ \\
\hline & Ability to serve customized orders - to adapt products & & $x$ \\
\hline & Ability for fast response & & $x$ \\
\hline & Innovative capacity & & $x$ \\
\hline & Knowledge of the country's support structure & & $x$ \\
\hline & Knowledge of cost structure for exporting & $x$ & $x$ \\
\hline & Knowledge of international business practices & $x$ & \\
\hline & Market knowledge & $x$ & $x$ \\
\hline & Knowledge of the own product and business & & $x$ \\
\hline & Supply contracts for the government & $x$ & \\
\hline & Contracts that ensure access to productive resources & $x$ & \\
\hline
\end{tabular}


(Figure 4.2 (continuation))

RESOURCES FOR THE INTERNATIONALIZATION OF SMES FROM EMERGING COUNTRIES IDENTIFIED BY THE SYSTEMATIC REVIEW VERSUS THOSE IDENTIFIED IN EXPLORATORY RESEARCH

\begin{tabular}{|c|c|c|c|}
\hline Category & Resource description & $\begin{array}{l}\text { Systematic } \\
\text { review }\end{array}$ & $\begin{array}{l}\text { Exploratory } \\
\text { research }\end{array}$ \\
\hline & Development of relationship with the customer & $x$ & $x$ \\
\hline & Appropriate package for the target market & & $x$ \\
\hline & Strategies for competitive cooperation & & $x$ \\
\hline & $\begin{array}{l}\text { Structure for product commercialization in the foreign } \\
\text { market }\end{array}$ & $x$ & $x$ \\
\hline & Internal communication structure & $x$ & \\
\hline & Competitive cost structure & $x$ & \\
\hline & Organizational structure oriented to foreign trade & & $x$ \\
\hline & Company's international experience & $x$ & $x$ \\
\hline & Experience in the domestic market & $x$ & $x$ \\
\hline & Flexible management & & $x$ \\
\hline & Global mindset & $x$ & $x$ \\
\hline \multirow[t]{11}{*}{ Organizational } & $\begin{array}{l}\text { Importer with size and management appropriate to } \\
\text { the company }\end{array}$ & & $x$ \\
\hline & $\begin{array}{l}\text { Promotional material, with package and site suitable for } \\
\text { the international market (language, content) }\end{array}$ & & $x$ \\
\hline & $\begin{array}{l}\text { Participation in international trade fairs, missions, and } \\
\text { events }\end{array}$ & $x$ & $x$ \\
\hline & Participation in networks and associations & $x$ & $x$ \\
\hline & Profile open to change & & $x$ \\
\hline & Export plan & $x$ & $x$ \\
\hline & Competitive price for the global market & & $x$ \\
\hline & Proactivity for international expansion & $x$ & $x$ \\
\hline & Competitive product in the foreign market & $x$ & $x$ \\
\hline & $\begin{array}{l}\text { Informal relationships with other key players for } \\
\text { internationalization }\end{array}$ & & $x$ \\
\hline & Cargo insurance & & $x$ \\
\hline
\end{tabular}




\section{(Figure 4.2 (conclusion))}

\section{RESOURCES FOR THE INTERNATIONALIZATION OF SMES FROM EMERGING COUNTRIES IDENTIFIED BY THE SYSTEMATIC REVIEW VERSUS THOSE IDENTIFIED IN EXPLORATORY RESEARCH}

\begin{tabular}{|c|c|c|c|}
\hline Category & Resource description & $\begin{array}{l}\text { Systematic } \\
\text { review }\end{array}$ & $\begin{array}{l}\text { Exploratory } \\
\text { research }\end{array}$ \\
\hline \multirow{9}{*}{ Reputational } & Certification of product origin and raw material & & $x$ \\
\hline & Globally recognized quality certificates & & $x$ \\
\hline & Multinational customer recognized in the global market & & $x$ \\
\hline & Company's history and tradition & & $x$ \\
\hline & Brand with international potential & $x$ & $x$ \\
\hline & International level awards & & $x$ \\
\hline & International recognition & & $x$ \\
\hline & Company's reputation & $x$ & $x$ \\
\hline & Product reputation in the domestic market & $x$ & \\
\hline \multirow{8}{*}{ Technological } & Structure for technical assistance or after-sales abroad & $x$ & $x$ \\
\hline & Production structure oriented to sustainability & & $x$ \\
\hline & Own structure for research and development (R\&D) & $x$ & $x$ \\
\hline & $\begin{array}{l}\text { Technological structure for communication and } \\
\text { negotiation with foreign markets }\end{array}$ & & $x$ \\
\hline & Product patent in Brazil or abroad & & $x$ \\
\hline & Exclusive production process & $x$ & \\
\hline & Production processes suitable for international demands & $x$ & $x$ \\
\hline & Technology with added value & & $x$ \\
\hline
\end{tabular}

Source: Elaborated by the authors.

We only found "access to third-party resources" and "financial resources for innovation" in the exploratory research. The other resources in this category appeared in both surveys. Dong and Men (2014) and Manolova et al. (2014) explain this result. These studies show that SMEs from emerging countries tend to internationalize by using mainly their own financial resources. According to the experts and market analysts interviewed, funding depends on SME's access to financial resources, such as internal liquidity and available tangible assets, since it is necessary to provide guarantees to 
the creditor. These issues regarding guarantees for financing are evident in the statements of the two bank interviewees.

[...] normally we work with a real guarantee, then we take a machine, a property, and sometimes the company doesn't have that, so it can hinder the process, although the vast majority have a collateral (BRDE interviewee)

Each company delivers the balance sheet to the bank, and the bank analyzes the financial data and the risk level of that company. It depends on the risk and depends on the guarantee that the firm will give to the bank (Bank of Brasil interviewee)

We classified organizational resources into three subcategories: knowledge resources and organizational structure, management resources, and operational resources (Figure 4.3). Knowledge resources and organizational structure cover both access to training and capacity building, as well as knowledge of the structures, markets, business, and the company's internal structure in terms of costs, communication, organization, and experience in the domestic and foreign markets. Management resources include those related to inter-organizational strategies and agreements (such as alliances, contracts, participation in networks and events), as well as the type of management and the prevailing managerial mindset in the company. Finally, operational resources refer to the creation of a company's service capacity, especially regarding innovation, delivery, and adequacy to market demands.

\section{(Figure 4.3)}

SUBCATEGORIES OF ORGANIZATIONAL RESOURCES FOR THE INTERNATIONALIZATION OF SMES FROM EMERGING COUNTRIES

\begin{tabular}{|c|c|}
\hline $\begin{array}{c}\text { Subcategory of } \\
\text { organizational resource }\end{array}$ & Resource description \\
\hline \multirow{5}{*}{$\begin{array}{l}\text { Knowledge and } \\
\text { organizational structure }\end{array}$} & Access to a structure for training and capacity building \\
\hline & Knowledge of the country's support structure \\
\hline & Knowledge of the cost structure for exporting \\
\hline & Knowledge of international business practices \\
\hline & Market knowledge \\
\hline
\end{tabular}




\section{(Figure 4.3 (continuation))}

\section{SUBCATEGORIES OF ORGANIZATIONAL RESOURCES FOR THE INTERNATIONALIZATION OF SMES FROM EMERGING COUNTRIES}

\begin{tabular}{|c|c|}
\hline $\begin{array}{l}\text { Subcategory of } \\
\text { organizational resource }\end{array}$ & Resource description \\
\hline \multirow{7}{*}{$\begin{array}{l}\text { Knowledge and } \\
\text { organizational structure }\end{array}$} & Knowledge of the own product and business \\
\hline & Structure for commercialization of products in the foreign market \\
\hline & Internal communication structure \\
\hline & Competitive costs structure \\
\hline & Organizational structure for foreign trade \\
\hline & Firm's international experience \\
\hline & Experience in the domestic market \\
\hline \multirow{15}{*}{ Managerial resources } & Cooperation or supply agreements for multinationals \\
\hline & Strategic alliances for internationalization \\
\hline & Supply contracts for the government \\
\hline & Contracts that ensure access to productive resources \\
\hline & Developing relationship with the customer \\
\hline & Competitive cooperation strategies \\
\hline & Flexible management \\
\hline & Global mindset \\
\hline & Importer with size and management appropriate to the company \\
\hline & Participation in international trade fairs, missions, and events \\
\hline & Participation in networks and associations \\
\hline & Profile open to change \\
\hline & Export plan \\
\hline & Proactivity for international expansion \\
\hline & Informal relationships with other key players for internationalization \\
\hline \multirow{4}{*}{ Operational resources } & Ability to serve customized orders \\
\hline & Ability for fast response \\
\hline & Innovative capacity \\
\hline & Appropriate package for the target market \\
\hline
\end{tabular}




\section{(Figure 4.3 (conclusion))}

SUBCATEGORIES OF ORGANIZATIONAL RESOURCES FOR THE INTERNATIONALIZATION OF EMERGING COUNTRIES' SMES

\begin{tabular}{ll}
$\begin{array}{c}\text { Subcategory of } \\
\text { organizational resource }\end{array}$ & \multicolumn{1}{c}{ Resource description } \\
\hline & $\begin{array}{l}\text { Promotional material, with package and site suitable for the } \\
\text { international market (language, content) }\end{array}$ \\
\cline { 2 - 2 } Operational resources & \begin{tabular}{l} 
Competitive price for the global market \\
\cline { 2 - 2 } Competitive product in the foreign market
\end{tabular} \\
\hline
\end{tabular}

As for human resources, those identified in the systematic review were also present in the exploratory research. However, exploratory research shows "entrepreneurial behavior oriented towards internationalization" and other resources considered by several experts as "basic", such as "people fluent in other languages" and "professionals with sales ability".

English is essential and preferably Spanish too, right? Because you are going to sell abroad, and you will receive a call from abroad, so there must be people who know how to speak, who are bilingual, trilingual, as well as to have promotional material. This is an investment (Interviewee Exporta RS).

These more essential resources possibly create competitive advantage when compared to firms in the Brazilian context, given the difficulties mentioned by experts to find professionals fluent in English and/or Spanish who also have the other skills required for working with international trade. Even without an export department in the SME, there must be professionals inside or outside the company to do this job. Therefore, outsourcing foreign trade activities can be more convenient to SMEs with low sales volume in the foreign market.

If you do not have qualified people, it seems to me that this is a very big Achilles heel. Because human resources ... how do I get experience for the company? I will search people involved in international management, if they have international experience, if they speak languages, if they have relationships (Expert 5). 
Connected to the human resources appointed by expert 5 are some of the knowledge and organizational structure resources to internationalize, which include "company's international experience" and "experience in the domestic market", as well as "knowledge of the country's support structure". The latter, mentioned only by the experts interviewed in the exploratory research, was shown by Machado (2010) to be positively related to SMEs' commitment to the international market.

However, resources such as "supply contracts for the government" and "contracts that ensure access to productive resources" were only mentioned in SLR. Such resources could facilitate entering the foreign market. However, apparently, this is not the case of Brazil since experts did not indicate them.

Management-related resources such as "flexible management" and "profile open to change", "strategies for competitive cooperation", and "informal relationships with other key players for internationalization” were considered managerial resources. Counting on importers who take over foreign market operations and "wear the company's shirt" was also considered an important resource. According to experts, small firms cannot depend on importers who demand large volumes of production or capital from SMEs. Therefore, choosing smaller importers who know how to manage image issues and identify and appreciate SMEs' strengths is important to add value in the foreign market. Importers' commitment to the company's internationalization is evident in the speech of wine industry representatives.

Therefore, many wineries adopt the strategy: I don't want to hear from the big ones (importers) anymore, because they are only interested in commodities, they are neither interested in investing in me, in my image, nor in creating demand; so, I have to go there, I have to pay to be there, to do a lot of things.

Operational resources, such as the ability to customize the product, answer the customer quickly, and innovate, were only mentioned in exploratory research. For appropriate communication to the foreign market, it is necessary to have promotional material, packaging, and a website in the language and with content that make the product more accessible. In addition, some Brazilian experts mention "cargo insurance" as critical, while in other contexts, it is a "basic" resource for internationalization and does not create competitive advantage.

Reputational resources such as a brand with international potential and the company's reputation were present both in the systematic review and in 
exploratory research. Yet, the product's reputation in the domestic market only appeared in the systematic review. Fensterseifer (2007) observes that there is a tendency for Brazilian consumers to value imported products more than domestic ones, as in the case of wines. On the other hand, a company with a good reputation is relevant because buyers from foreign markets can easily check certifications, awards, and international recognition, which are competitiveness factors. In addition, international certifications and awards place products from an emerging country at the same level of quality as products from developed countries.

Product's reputation certification is also important for meeting specific requirements of the target market. As specialist 2 says,

There are products that need European Union certification that require a laboratory analysis before leaving Brazil. For example, it is always good to ask your customer overseas if his country has any special requirements for the product you are selling. Based on that, you do it.

The SMEs' history is also valued, but experts mentioned that its importance varies according to the sector, being relevant in the cachaça and wine industry. As respondents from these sectors observe:

[We] sell culture, tradition, and years of the company. And I say a lot to my client $[. .$.$] being a family business, it has a lot of added value in$ Europe (Cachaça industry interviewee).

[...] sometimes, it draws the consumer's attention, from the person who will import, etc. This is a history of dedication, production is small, and the product is made manually. Therefore, it has this advantage (IBRAVIN interviewee).

In exploring the company's history, it is necessary to analyze, in particular, SME's characteristics, such as the type of management - family or professional -, the origin of the company's resources, sectors linked to sustainable production chains, and other factors that we did not address in this research.

Regarding technological resources, most of those identified in SLR were present in the exploratory research, like "structure for technical assistance or after-sales abroad", "R\&D own structure", and "production processes suitable for international demands". Yet, the "exclusive production process" 
resource does not appear in the exploratory research, perhaps because in Brazil it is a scarcer resource, considering companies' low technological intensity (Carvalho \& Avellar, 2013). On the other hand, only the exploratory research identified resources such as "production structure oriented to sustainability", "technological structure for communication and negotiation with foreign markets", "product's patent in Brazil or abroad", and "technology with added value". This is also consistent with SMEs' low technological intensity.

\subsection{Main findings}

Research results indicate that most of the 72 country resources identified in the internationalization of SMEs from emerging economies are organizational and, from them, we proposed three large groups: 1. resources linked to knowledge and organizational structure; 2. management resources; and 3. operational resources. These resources can be examined according to their use at different levels of the company, such as the strategic, tactical, and operational levels since they refer to the company's strategic thinking capacity, organization, execution, and delivery to market demands.

Among the resources classified by Grant (1991), the type with the least potential for creating competitive advantage is the physical. These resources do not appear in SLR, and the exploratory research hardly mentions them due to the ease of imitation (Fahy, 2002). Confirming previous studies, physical resources, which are tangible, seem to have less strategic value for internationalization than intangible resources, such as organizational.

Although there are studies in other emerging countries that show the difficulty of SMEs from emerging countries to access "traditional" resources (Gaur et al., 2014), the results are more in line with Torrens et al. (2014), who identified access to some of these traditional resources, such as firm's international experience. On the other hand, some identified resources may be classified as "non-traditional" (Gaur et al., 2014), as they proved to be relevant in the exploratory research and, according to the interviewees, are often neglected by SMEs, especially Brazilian ones, despite their relevance in the foreign market. Some examples are cargo insurance, promotional material suitable for the foreign market, and people fluent in other languages.

Regarding studies on resources for internationalization of SMEs from emerging countries, according to our search criteria, of the 15 articles that comprised the systematic review, seven addressed Asian countries, which shows their representation in this topic. The samples are multisector, and 
most methodologies are quantitative. Multisector studies can undermine the identification of certain types of critical resources for the internationalization process due to a superficial interpretation of results. We observed the low variety of methods used in research on this topic, possibly due to the exploratory nature of the sample studies. Therefore, it is necessary to advance, both theoretically and empirically, in studies on SMEs from emerging countries, aiming to compare countries according to their institutional context, companies' attributes, and available resources.

\section{FINAL REMARKS}

This paper aimed to identify and classify country-level resources for the internationalization of SMEs from emerging economies. Thus, the results present theoretical and methodological contributions and managerial implications for the development of internationalization strategies in the context of emerging countries. As a theoretical contribution, the results are a guide for the theoretical building of internationalization models that should be empirically checked, especially regarding firm internal resources. As for the identified resources, those considered "basic" or "less strategic" should be explored in future studies by using other classifications, as proposed by Fahy (2002), adapting them to SMEs' resources for each emerging country.

As for the methodology, this paper contributed by using data from primary sources, such as interviews, and secondary, like the systematic literature review, applying them to a specific context. Future research may use the classification proposed here for studies on specific sectors, thus reducing the limitations of this research that result from sectorial issues and expanding its replicability and possibility of comparison. We also suggest conducting a survey with companies from other emerging countries, under the same perspective adopted here, in order to identify other resources at the firm level that stem from contextual factors.

Regarding managerial implications, this study presents a classification of resources that can guide SMEs in preparing internationalization strategies. Likewise, they can serve for the discussion and development of public policies that foster such strategies. Some policies are already present in programs of the Federal Government and its partners, such as the Qualification Program for Export (Peiex), of the Brazilian Agency for Promotion of Exports and Investments (Apex-Brasil, 2020), for the qualification of managers of Brazilian companies that wish to internationalize. It is important to keep 
Brazilian policies that foster internationalization, which have been historically discontinued (Machado, 2010). Therefore, our research results can strengthen these programs in order to meet the demands, supporting the permanence and growth of SMEs in the international market.

\section{RECURSOS DA FIRMA PARA INTERNACIONALIZAÇÃO DE PMES DE PAÍSES EMERGENTES: ESTUDO MULTIMÉTODO}

\section{RESUMO}

Objetivo: Investigar e classificar recursos para internacionalização de pequenas e médias empresas (PMEs) de países emergentes.

Originalidade/valor: A participação de PMEs de países emergentes em mercados globais evidencia seu acesso mais restrito aos recursos para internacionalização. A literatura dominante de negócios internacionais segue classificações de recursos identificados em grandes empresas de economias desenvolvidas. Esta pesquisa classifica recursos da firma para internacionalização de PMEs baseada em diferentes países emergentes, com dados de revisão sistemática de literatura (RSL) e entrevistas. O artigo contribui para o desenvolvimento teórico sobre a internacionalização de PMEs de países emergentes, indicando a importância dos recursos organizacionais nesse processo.

Design/metodologia/abordagem: Este artigo apresenta uma pesquisa exploratória, de abordagem qualitativa, desenvolvida em duas etapas: RSL, abrangendo diferentes países emergentes, seguida de entrevistas com especialistas, instituições e PMEs no contexto brasileiro. Adotaram-se técnicas de coleta de dados de pesquisa bibliográfica e entrevista com roteiro semiestruturado. A análise das entrevistas baseou-se em técnica de análise de conteúdo e categorização dos recursos, com o software NVivo. Resultados: Até 2016, 15 trabalhos mencionaram recursos para internacionalização de PMEs de países emergentes e sete foram feitos na Ásia. Identificaram-se 72 recursos em dez países emergentes. Predominam recursos organizacionais. O uso de recursos financeiros de terceiros no Brasil contradiz tendências em outros países emergentes. Recursos tangíveis parecem ter menor importância estratégica para a internacionalização do que recursos intangíveis, como os organizacionais. 


\section{PALAVRAS-CHAVE}

Visão baseada em recursos. Revisão sistemática. Países emergentes. Pequenas e médias empresas. Exportação.

\section{$\int$ REFERENCES}

Acikdilli, G., Mintu-Wimsatt, A., Kara, A. \& Spillan, J. (2020). Export market orientation, marketing capabilities and export performance of SMEs in an emerging market: A resource-based approach. Journal of Marketing Theory and Practice. Advance online publication. doi:10.1080/10696679.2020.1809461

Agência Brasileira de Promoção de Exportações e Investimentos (2020). Programa de Qualificação para Exportação. Retrieved from https://portal. apexbrasil.com.br/qualifique-sua-empresa-peiex

Ahmad, S. Z. (2014). Small and medium enterprises' internationalisation and business strategy: Some evidence from firms located in an emerging market. Journal of Asia Business Studies, 8(2), 168-186. doi:10.1108/JABS03-2013-0012

Ayob, A. H., Ramlee, S., \& Rahman, A. (2015). Financial factors and export behavior of small and medium sized enterprises in an emerging economy. Journal of International Entrepreneurship, 13, 49-66. doi:10.1007/s10843014-0141-5

Bardin, L. (2011). Análise de conteúdo. São Paulo: Edições 70.

Barney, J. B. (1991). Firm resources and sustained competitive advantage. Journal of Management, 17(1), 99-120. doi:10.1177/014920639101700108

Bhaumik, S., Driffield, N., Gaur, A., Mickiewicz, T., \& Vaaler, P. (2019). Corporate governance and MNE strategies in emerging economies. Journal of World Business, 54(4), 234-243. doi:10.1016/j.jwb.2019.03.004

Cardoza, G., Fornes, G., Li, P., Xu, N., \& Xu, S. (2015). China goes global: Public policies' influence on small and medium-size enterprises' international expansion. Asia Pacific Business Review, 21 (2), 188-210. doi:10.1080/ 13602381.2013.876183

Carvalho, D. M., Prévot, F., \& Machado, J. A. D. (2014). O uso da teoria da visão baseada em recursos em propriedades rurais: Uma revisão sistemática da literatura. RAUSP Management Journal, 49(3), 506-518. doi:10.5700/ rausp1164 
Carvalho, L., \& Avellar, A. P. M. (2013). Inovação e produtividade: Evidências empíricas para empresas brasileiras. Anais do Encontro Nacional de Economia, Foz do Iguaçu, PR, Brasil, 41.

Cavusgil, S. T., Ghauri, P. N., \& Akcal, A. A. (2013). Doing business in emerging markets. Thousand Oaks, CA: Sage.

Chandra, A., Paul, J., \& Chavan, M. (2020). Internationalization barriers of SMEs from developing countries: A review and research agenda. International Journal of Entrepreneurial Behavior \& Research, 26(6), 1281-1310. doi:10.1108/IJEBR-03-2020-0167

Che Senik, Z., Mat Isa, R., Md Sham, R., \& Ayob, A. H. (2014). A model for understanding SMEs internationalization in emerging economies. Jurnal Pengurusan, 41, 25-42.

Contractor, F. J., Kumar, V., \& Kundu, S. (2007). Nature of the relationship between international expansion and performance: The case of emerging market firms. Journal of World Business, 42, 401-417. doi:10.1016/j. jwb.2007.06.003

Dong, Y., \& Men, C. (2014). SME financing in emerging markets: Firm characteristics, banking structure and institutions. Emerging Markets Finance $\mathcal{E}$ Trade, 50(1), 120-149. doi:10.2753/REE1540-496X500107

Fahy, J. A. (2002). A resource-based analysis of sustainable competitive advantage in a global environment. International Business Review, 11, 57-78. doi:10.1016/S0969-5931(01)00047-6

Falagas, M. E., Pitsouni, E. I., Malietzis, G. A., \& Pappas G. (2008). Comparison of PubMed, Scopus, Web of Science, and Google Scholar: Strengths and weaknesses. FASEB Journal, 22(2), 338-342. doi:10.1096/fj.07-94 92LSF

Fensterseifer, J. E. (2007). The emerging Brazilian wine industry: Challenges and prospects for the Serra Gaúcha wine cluster. International Journal of Wine Business Research, 19(3), 187-206. doi:10.1108/17511060710817221

Fleury, A., \& Fleury, M. T. L. (2007). Internacionalização de empresas brasileiras: Em busca de uma abordagem teórica para os late movers. In A. Fleury \& M. T. L. Fleury (Orgs.), Internacionalização e os países emergentes (pp. 3-14). São Paulo: Atlas.

Gaur, A. S., Kumar, V., \& Singh, D. (2014). Institutions, resources, and internationalization of emerging economy firms. Journal of World Business, 49(1), 12-20. doi:10.1016/j.jwb.2013.04.002 
Grant, R. M. (1991). The resource-based theory of competitive advantage: Implications for strategic formulation. California Management Review, 33 (3), 114-135. doi:10.2307/41166664

Hernandez, E., \& Guillen, M. (2018). What's theoretically novel about emerging market multinationals? Journal of International Business Studies, 49, 24-33. doi:10.1057/s41267-017-0131-7

Javalgi, R. G., \& Todd, P. R. (2011). Entrepreneurial orientation, management commitment, and human capital: The internationalization of SMEs in India. Journal of Business Research, 64, 1004-1010. doi:10.1016/j.jbusres. 2010.11.024

Kamakura, W. A., Ramón-Jerónimo, M. A., \& Gravel, J. D. V. (2012). A dynamic perspective to the internationalization of small-medium enterprises. Journal of the Academy of Marketing Science, 40(2), 236-251. doi:10.1007/s11747-011-0267-0

Kazlauskaitè, R., Autio, E., Gelbūda, M., \& Šarapovas, T. (2015). The resource-based view and SME internationalisation: An emerging economy perspective. Entrepreneurial Business and Economics Review, 3(2), 53-64. doi:10.15678/EBER.2015.030205

Keen, C. (2013). Tangible and intangible internationalisation of SMEs: The Argentinean case. International Journal of Entrepreneurship and Small Business, 19(3), 399-420.

Ketkar, S., \& Acs, Z. J. (2013). Where angels fear to tread: Internationalization of emerging country SMEs. Journal of International Entrepreneurship, 11, 201-209. doi:10.1007/s10843-013-0107-z

Kocak, A., \& Abimbola, T. (2009). The effects of entrepreneurial marketing on born global performance. International Marketing Review, 26(4-5), 439-452. doi:10.1108/02651330910971977

Kraaijenbrink, J., Spender, J.-C., \& Groen, A. J. (2010). The resource-based view: A review and assessment of its critiques. Journal of Management, 36(1), 349-372. doi:10.1177/0149206309350775

Lafuente, E., Stoian, M., \& Rialp, J. (2015). From export entry to deinternationalisation through entrepreneurial attributes. Journal of Small Business and Enterprise Development, 22(1), 21-37.

Lee, H., Lee, K., \& Kwak, J. (2013). Sequential internationalization of smalland medium-sized enterprises from newly industrializing economies: The Korean experience in China. Asian Business and Management, 12 (1), 61-84. doi:10.1057/abm.2012.28 
Machado, M. A. (2010). Impacto da orientação internacional, comprometimento e apoio à exportação sobre o desempenho das pequenas e médias empresas: Um estudo das PMEs brasileiras de internacionalização rápida e tradicional (Tese de doutorado, Universidade Federal do Rio Grande do Sul, Porto Alegre, Brasil).

Manolova, T. S., Manev, I. M., \& Gyoshev, B. S. (2014). Friends with money? Owner's financial network and new venture internationalization in a transition economy. International Small Business Journal, 32(8), 1-23. doi:10.11 77/0266242613482482

Nanda, A. (1996). Resources, capabilities and competencies. In B. Moingeon \& A. Edmonson (Eds.), Organizational learning and competitive advantage (pp. 93-120). Thousand Oaks, CA: Sage.

Nason, R., \& Wiklund, J. (2018). An assessment of resource-based theorizing on firm growth and suggestions for the future. Journal of Management, 44(1), 32-60. doi:10.1177/0149206315610635

Oura, M. M., Zilber, S. N., \& Lopes, E. L. (2016). Innovation capacity, international experience and export performance of SMEs in Brazil. International Business Review, 25(4), 921-932. doi:10.1016/j.ibusrev.2015.12.002

Pattnaik, C., \& Elango, B. (2009). The impact of firm resources on the internationalization and performance relationship: A study of Indian manufacturing firms. Multinational Business Review, 17(2), 69-88. doi:10.1108/15 25383X200900010

Peng, M., Wang, D., \& Jiang, Y. (2008). An institution-based view of international business strategy: A focus on emerging economies. Journal of International Business Studies, 39(5), 920-936. doi:10.1057/palgrave.jibs. 8400377

Penrose, E. (1959). The theory of the growth of the firm. New York: Oxford University Press.

Peteraf, M. A. (1993). The cornerstones of competitive advantage: A resource based-view. Strategic Management Journal, 14, 179-191.

Prévot, F., Brulhart, F., \& Guieu, G. (2010). Perspectives fondées sur les ressources: Proposition de synthèse. Revue Française de Gestion, 204, 87-102. doi:10.3166/rfg.204.87-103

Torrens, E. W., Amal, M., \& Tontini, G. (2014). Determinantes do desempenho exportador de pequenas e médias empresas manufatureiras brasileiras sob a perspectiva da visão baseada em recursos e do modelo de Uppsala. Revista Brasileira de Gestão de Negócios, 16(53), 511-539. doi:10.7819/rbgn. v16i52.1601 
Tranfield, D., Denyer, D., \& Smart, P. (2003). Towards a methodology for developing evidence-informed management knowledge by means of systematic review. British Journal of Management, 14, 207-222. doi:10.1111/ 1467-8551.00375

Victer, R. S. (2014). The comparative relevance of resource heterogeneity and resource mobility to strategic management. Journal of International Business Disciplines, 9(1), 61-76.

Volchek, D., Jantunen, A., \& Saarenketo, S. (2014). The institutional environment for international entrepreneurship in Russia: Reflections on growth decisions and performance in SMEs. Journal of International Entrepreneurship, 11, 320-350. doi:10.1007/s10843-013-0115-z

Wernerfelt, B. (1984). A resource-based view of the firm. Strategic Management Journal, 5, 171-180.

Williams, D. (2008). Export stimulation of micro-and small locally owned firms from emerging environments: New evidence. Journal of International Entrepreneurship, 6, 101-122. doi:10.1007/s10843-008-0022-x

Winckler, N. C. (2018). Recursos do país na internacionalização de países emergentes: Um estudo no contexto brasileiro (Tese de doutorado, Universidade Federal do Rio Grande do Sul, Porto Alegre, Brasil).

Wright, M., Westhead, P., \& Ubasaran, D. (2007). Internationalization of small and medium-sized enterprises (SMEs) and international entrepreneurship: A critique and policy implications. Regional Studies, 41, 1013-1029. doi:10.1080/00343400601120288

Wu, B., \& Deng, P. (2020). Internationalization of SMEs from emerging markets: An institutional escape perspective, Journal of Business Research, 108, 337-350. doi:10.1016/j.jbusres.2019.10.037

Zhang, M., Wheeler, J., Gao, Q., \& Kwon, J. (2016). Institutional effect on born global firms in China: The role of Sun Tzu's The Art of War strategies. Journal of Asia Business Studies, 10(1), 1-19. doi:10.1108/JABS-11-2014-0084

\section{AUTHOR NOTES}

Natália C. Winckler, Ph.D. from the Graduate Program in Administration, Federal University of Rio Grande do Sul (UFRGS); Aurora C. Zen, Ph.D. from the School of Administration, UFRGS; Frédéric Prevot, Ph.D. from the Faculty of Management Sciences, Aix-Marseille University.

Natália C. Winckler is now alumna of UFRGS and consultant and entrepreneur; Aurora C. Zen is now an associate professor at the Department of Administrative Sciences of UFRGS; Frédéric Prevot is now a full professor at the Department of Strategy of Kedge Business School. 
Correspondence concerning this article should be addressed to Natália C. Winckler, Rua Curupaiti, 1326, ap. 404, Cristal, Porto Alegre, Rio Grande do Sul, Brazil, CEP 90820-090.

E-mail: nataliawinckler@gmail.com

\section{EDITORIAL BOARD}

Editor-in-chief

Gilberto Perez

Associate editors

Francisco Américo Cassano and

Alexandre Cappellozza

Technical support

Vitória Batista Santos Silva

\section{EDITORIAL PRODUCTION}

Publishing coordination Jéssica Dametta

Language editor

Daniel de Almeida Leão

Layout designer

Emap

Graphic designer

Libro 